\title{
Placental PAGs: gene origins, expression patterns, and use as markers of pregnancy
}

\author{
Rhianna M Wallace, Ky G Pohler, Michael F Smith and Jonathan A Green \\ Division of Animal Sciences, 163 Animal Sciences Research Center, University of Missouri, \\ Columbia, Missouri 65211, USA \\ Correspondence should be addressed to J A Green; Email: greenjo@missouri.edu
}

\begin{abstract}
Pregnancy-associated glycoproteins (PAGs) are abundantly expressed products of the placenta of species within the Cetartiodactyla order (even-toed ungulates). They are restricted to this order and they are particularly numerous in the Bovidae. The PAGs exhibit a range of temporal and spatial expression patterns by the placental trophoblasts and probably represent a group of related proteins that perform a range of distinct functions in the epitheliochorial and synepitheliochorial placental forms. This review presents an overview of the origins of the PAGs, a summary of PAG expression patterns, and their use as markers of pregnancy status. Speculations about their putative role(s) in pregnancy are also presented.

Reproduction (2015) 149 R115-R126
\end{abstract}

\section{Introduction}

Pregnancy-associated glycoprotein (PAG) was identified by three independent research groups, explaining the process of its purification from bovine placental extracts and its accumulation in maternal blood (Butler et al. 1982, Sasser et al. 1986, Zoli et al. 1991, 1992, Mialon et al. 1993, 1994). Other names for PAG include pregnancy-specific protein B (PSPB) and PSP of 60000 molecular weight (PSP60). For the purposes of this review, we will use the acronym 'PAG' or 'PAG1' (when referring to the first, or archetypal, member of the family). After the initial discovery of PAG, subsequent studies revealed an unanticipated complexity in the number of PAGs as well as in the nature of their expression by the placenta. It has become clear that the PAGs represent an unusual gene family that probably plays important roles in the function of the placenta in even-toed ungulates. This review attempts to give the reader an appreciation for the size and scope of the PAG family. It will present an overview of PAG production by the placenta. It will also provide some speculation about their putative roles in pregnancy and describe how PAGs can serve as useful markers for pregnancy detection and placental viability.

\section{The PAG family}

PAGs are abundantly expressed products of the placenta of species within the Cetartiodactyla order (even-toed ungulates; Szafranska et al. 1995, Xie et al. 1997,
Garbayo et al. 2000, Green et al. 2000, Majewska et al. 2006, Brandt et al. 2007, Barbato et al. 2008, Majewska et al. 2011, Bériot et al. 2014). They are represented in current sequence databases comprising Suidae (e.g. swine), Cetacea (e.g. orca), and Pecora (e.g. deer, domestic cattle, and giraffe) genome sequences, cDNAs, and ESTs.

Phylogenetic analyses have indicated that PAGs can be segregated into at least two groupings that were loosely defined as 'ancient' and 'modern' based on the time when each group arose (Hughes et al. 2000). The ancient PAGs are predicted to have originated $\sim 87$ million years ago, while the modern PAGs were estimated to have arisen 52 million years ago (Hughes et al. 2000; Fig. 1). The majority of PAGs belong to the modern group and these have only been observed in the Ruminantia, with a particularly large expansion in the Bovidae (cattle, sheep, etc.; Telugu et al. 2009). Indeed, the current bovine and ovine genome builds contain at least two dozen intact PAG genes as well as numerous PAG gene models that may encode functional proteins. Perhaps not unexpectedly, the sheer number and complexity of the PAG family leads to difficulty in nomenclature. For the most part, individual PAGs have been named using a numerical approach based on the order in which PAG cDNAs were subcloned and sequenced. Other PAGs are known only by their unique accession or locus identifier numbers. Some confusion can arise from this naming approach because the names of individual PAGs are rarely reflective of orthology (e.g. bovine PAG10 is not the ortholog for caprine PAG10, etc.). As the number and type of PAGs 


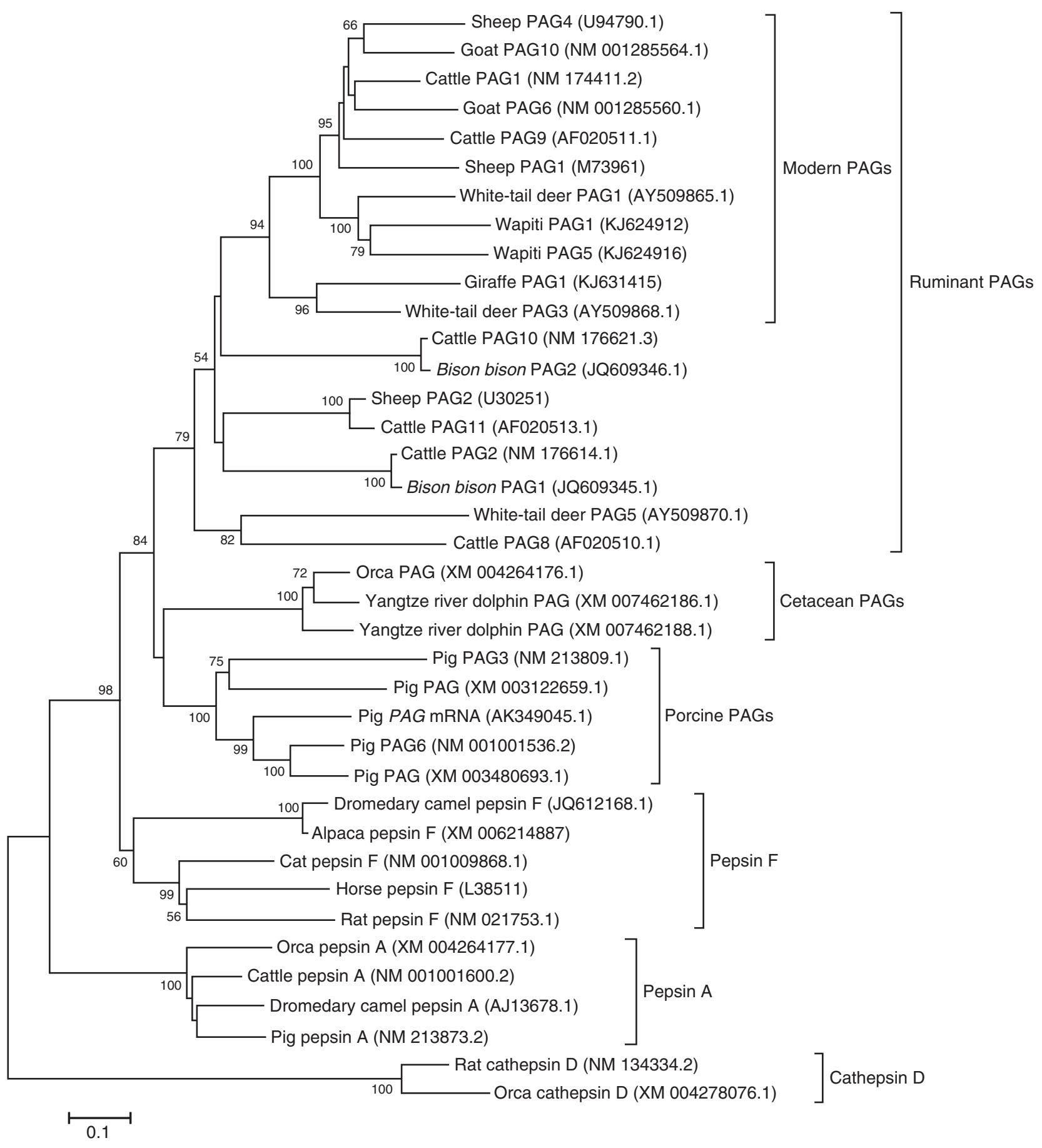

Figure 1 Phylogenetic tree of representative PAGs and other aspartic proteinases. Selective PAG-coding sequences were translated and aligned with representatives of the pepsin $\mathrm{F}$, pepsin $\mathrm{A}$, and cathepsin D families of proteolytic enzymes. A minimum evolution tree was used to represent the phylogenetic relationships. Genomic sequences and mRNAs that encode PAGs have been identified in three suborders within the Cetartiodactyla (Ruminantia, Cetacea, and Suidae). The majority of PAGs have been identified in the Ruminantia. The PAGs in this grouping consist of 'modern' PAGs that arose relatively recently; these are particularly well represented in the Bovidae. The 'ancient' PAGs are fewer in number and may reflect an origin that corresponds to around a time when the suborders within the Cetartiodactyl began to diverge. The PAGs chosen for the tree are displayed with a common name along with their unique GenBank accession number. The optimal tree from the analysis is shown. The percentage of replicate trees in which the associated members clustered together in the bootstrap test (1000 replicates) is shown next to the branches (only those with values $>50 \%$ are shown). The tree is drawn to scale, with branch lengths in the same units as those of the evolutionary distances used to infer the tree. The evolutionary distance, which is shown in the key at the bottom, is reflective of the number of amino acid substitutions per site. The phylogenetic analyses were conducted in the MEGA6 program (Tamura et al. 2013). 
across the Cetartiodactyla become more clear, a more informative and useful nomenclature will need to be established for this grouping.

The extensive PAG gene family appears to have arisen by duplication and the subsequent expansion of a gene known as 'pepsinogen $F^{\prime}$, which itself arose from duplication of an ancestral pepsinogen A-like gene (Hughes et al. 2003; Fig. 1). Both pepsin F and pepsin A are enzymes that belong to the aspartic proteinase family (Davies 1990, Dunn 2002). The aspartic proteinases possess a roughly symmetrical bilobed conformation that contains a cleft used to bind substrate proteins. Each lobe contributes an aspartic acid within a highly conserved sequence motif (Asp-Thr/Ser-Gly-Thr/Ser-Thr/Ser). The aspartic acids, along with a water molecule that is complexed between them, are critical for hydrolysis of substrate peptides. The central role of the aspartic acids in the catalytic mechanism is the reason for the name of this particular group of enzymes (Davies 1990). Interestingly, the first PAGs that were cloned (bovine and ovine PAG1) either lacked one of the catalytic aspartates (ovine PAG1) or lacked one of the adjacent conserved residues (bovine PAG1) (Xie et al. 1991, Green et al. 1998). Consequently, these specific PAGs are probably incapable of acting as proteolytic enzymes. Subsequent cloning of additional PAGs revealed others that are also unlikely to be enzymes because of mutations within key residues in and around the catalytic site (Guruprasad et al. 1996, Xie et al. 1997, Green et al. 2000, Brandt et al. 2007). However, the majority of PAGs contain conserved features typically found in functional aspartic proteinases. In fact, proteolytic activity has been confirmed for a few of them (Telugu \& Green 2008, Telugu et al. 2010). The extent to which the proteolytic activity of PAGs is relevant to their function during pregnancy is unclear, but some speculation about how such activity could reflect their role(s) in pregnancy is discussed later in this review.

\section{Temporal and spatial expression of PAGs in the placenta}

The localization and expression of PAGs have been most characterized in cattle with some work carried out in other ruminants and swine too. As mentioned in the previous section, the PAGs are particularly numerous in ruminant ungulates. This expansion of PAGs in Ruminantia is intriguing because there are aspects of the ruminant placenta that distinguish it from other species in the Cetartiodactyla - most of which have a diffuse epitheliochorial placental form (King 1993). The synepitheliochorial placenta of ruminants has a number of intriguing characteristics including: i) two distinct trophoblast cell populations: binucleated giant trophoblasts and mononucleated trophoblasts; ii) multinucleated fetal-maternal syncytial cells that are formed by the fusion of trophoblast binucleated cells with uterine epithelial cells; and iii) regions of placentauterine interactions (in pecoran ruminants) that consist of villous chorionic 'cotyledons' that interdigitate with aglandular maternal uterine caruncles to form 'placentomes'. Interestingly, there is an exception in the Ruminantia suborder with regard to the third feature. Species in the Tragulidae family (chevrotain or mouse deer) have a diffuse placenta with no placentomes, although they do possess binucleated giant trophoblasts within their trophectodermal villi (Kimura et al. 2004). These binucleated cells express PAGs that cross-react immunologically with those from the 'modern' grouping of other ruminants (Wooding et al. 2007).

In domestic cattle, binucleated giant trophoblasts first begin to appear around the end of the 3rd week of pregnancy. They arise from mononucleated trophoblasts via mitotic polyploidy (Wathes \& Wooding 1980, Wooding 1983, 1984). At some point after they form, each mature binucleated cell will migrate through the microvillar junction (between the trophoblasts and the uterine epithelia) and fuse with a uterine epithelial cell to form a syncytial fetal-maternal cell. Subsequent fusion events lead to multinucleated syncytia. In Caprinae, such as sheep and goats, the syncytia persist throughout the pregnancy (Lee et al. 1985, Wooding et al. 1986). In cattle, a syncytial layer is rarely observed after approximately day 40 of gestation; instead, the fusion event results in short-lived fetal-maternal trinucleated cells (Wathes \& Wooding 1980). As was mentioned previously, these specialized binucleated trophoblasts, along with their distinct fusogenic capacity, distinguish the ruminant placenta from the epitheliochorial placenta. The ability to breach the uterine epithelial layer establishes a more direct access to maternal tissues compared with species with an epitheliochorial placenta. Consequently, the nature of fetal-maternal interactions can be quite distinct between these species, especially in the ability to deliver placental protein directly into the maternal system. Many proteins, such as the PAGs, placental lactogen, and the prolactin-related proteins, are located within secretory granules of binucleated trophoblasts (Duello et al. 1986, Faria et al. 1990, Xie et al. 1991, Green et al. 2000, Patel et al. 2004a). Upon release of the secretory granules, the binucleated cell-expressed proteins are delivered to the maternal uterine connective tissue and some of these can make their way into the maternal blood circulation (Sasser et al. 1986, Zoli et al. 1992, Green et al. 2005).

The initial characterization of PAG expression in ruminant placentomes was performed by examining PAG transcripts via in situ hybridization of nucleotide probes in bovine, ovine, and caprine placentomes (Garbayo et al. 2000, Green et al. 2000). These studies revealed two basic expression patterns. Some PAGs were expressed in all trophoblasts (both mononucleated and binucleated), whereas others were localized to the 
binucleated trophoblast giant cell population alone. At the time, this general distribution pattern seemed to correlate with PAG phylogeny, with ancient PAGs being present in all trophoblasts and modern PAGs being restricted to binucleated cells (Green et al. 2000). Subsequent works in other species as well as more systematic localization (with PAG-specific antibodies) have indicated that the relationship between cell expression and PAG phylogeny is not so simplistic. For example, there are ancient PAGs in cervids (deer PAG4 and PAG5) that appear to be restricted to binucleated trophoblasts, while deer PAG3 (a modern PAG) was found to be expressed in both mononucleated and binucleated trophoblast cells (Brandt et al. 2007). Indeed, immunolocalization with antibodies to bovine PAG10 (an ancient PAG) also exhibit binucleated cell localization despite that the message for bovine PAG10 seemed to have a broader trophoblast distribution (Green et al. 2000) (Fig. 2A). In contrast, another ancient bovine PAG (PAG8) exhibits immunolocalization to mononucleated trophoblasts, with a noticeable absence of expression in binucleated cells (Fig. 2C).

The first systematic evaluation of PAGs by immunolocalization was performed by Wooding et al. (2005) in cattle. As was reported for the in situ hybridization experiments, they also observed that certain PAGs were localized exclusively to binucleated cells. Interestingly, some of these PAGs were shown to accumulate in the uterine stroma after release from the binucleate cell secretory granules (Fig. 2A and B). In contrast, other PAGs, such as bovine PAG2, were found to be expressed in all mononucleated trophoblasts, with localization to some, but not all, binucleated cells (Fig. 2D). For those PAGs exhibiting this expression pattern, the secreted PAGs accumulated at the microvillar junction in a manner similar to what was also observed at the pig placenta-uterine interface (Wooding et al. 2005). It is worth noting that a recent published work by Touzard et al. (2013) also investigated the expression of bovine PAG2 by immunolocalization. They observed mononucleated trophoblast staining, but they did not report immunolocalization of their anti-bovine PAG2 peptide antibody to binucleated trophoblasts.

Early attempts to quantify differences in relative transcript abundance in bovine placenta were made by Patel et al. (2004b) and Telugu et al. (2009). In the former, the authors focused on two of the modern PAG members (bovine PAG1 and PAG9). They demonstrated that bovine PAG9 message was approximately ten times greater in abundance early in gestation (days 30 and 60) compared with the message for bovine PAG1; those results were consistent with previous reports that measured these same gene products qualitatively by RNase protection assays and northern blotting (Green et al. 2000). Telugu et al. chose to investigate transcript abundance of five ancient bovine PAGs from day 45 until day 280 of gestation. A range of message profiles were

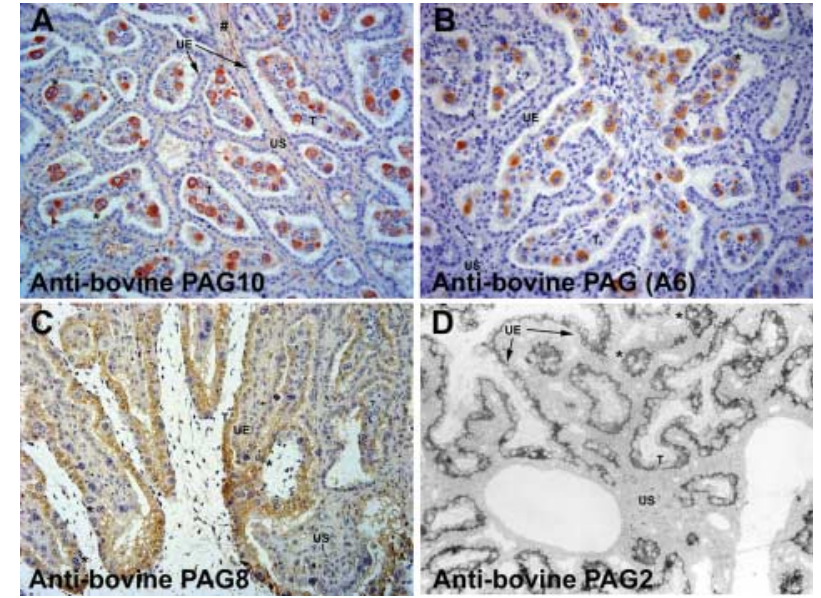

Figure 2 Representative patterns of PAG immunolocalization in bovine placentome sections. Some variation in the localization of PAGs is apparent in bovids. Many PAGs are expressed by binucleate trophoblast giant cells ( $\mathrm{A}$ and $\mathrm{B}$ ). These cells can deliver the contents of their secretory granules (which includes PAGs along with other proteins) to maternal tissues upon fusion with a uterine epithelial cell. Some or all of the PAGs released in this manner can enter the maternal circulation. A subset of these PAGs can also become sequestered in the maternal uterine connective tissue; an example of such immunolocalization is indicated with the symbol (\#) in A (see also Wooding et al. (2005)). Another pattern observed is one in which localization is observed in mononucleate trophoblasts and the microvillar junction. In some cases, expression is undetectable in the binucleate trophoblast population (C). For other PAGs, there is localization to mononucleate trophoblasts and some, but not all, binucleate trophoblasts. (A) Immunostaining of a day 60 placentome section with an antibody raised against recombinant bovine PAG10. (B) Immunostaining of a day 75 placentome section with an MAB (A6) directed against multiple modern bovine PAGs (see Green et al. (2005)). (C) Immunostaining of a day 90 placentome section with an antibody raised against recombinant bovine PAG8. (D) Immunostaining of a day 150 placentome section with an antibody raised against recombinant bovine PAG2; the image was generously provided by Peter Wooding (Cambridge University). It is used with his permission. $\mathrm{T}$, trophoblasts; UE, uterine epithelia; US, uterine stroma; and *binucleate trophoblast giant cells.

identified, some of which were dramatically different from one another. For example, bovine PAG8 and PAG11 transcripts were found to be highest in day 45 cotyledonary RNA compared with other stages. In contrast, bovine PAG10 message was maximal in the day 280 cotyledonary samples. A recent paper from Touzard et al. (2013) sought to further characterize bovine PAG message and protein abundance in both cotyledonary and intercotyledonary chorion. These authors observed that most, but not all, of the modern PAGs were two to four times more abundant in cotyledons compared with intercotyledonary chorion. In contrast, most of the ancient PAG transcripts they tested were elevated in the intercotyledonary chorion compared with cotyledons. Immunolocalization with anti-peptide PAG antibodies performed on placentomes and intercotyledonary sections at day 220 of gestation revealed that bovine PAG1 and bovine PAG2 were 
present in binucleated and mononucleated cotyledonary trophoblasts respectively. Little or no staining was observed for bovine PAG2 in the intercaruncular chorion. Interestingly, antibody directed toward bovine PAG11-labeled binucleated trophoblasts from both the day 220 placentome and the intercotyledonary chorion despite that PAG11 is an ancient PAG. Although it was not examined by immunolocalization, Western blotting with the bovine PAG11 antibody strongly labeled proteins from day 16 bovine conceptuses, which occurs before the time when binucleated trophoblasts are formed in cattle (Wathes \& Wooding 1980). These data may suggest that a change in cell-specific expression occurs over the course of placental development for this particular PAG. Finally, the report by Touzard et al. (2013) also provided some evidence that binucleated trophoblasts may represent distinct cell populations that are distinguishable based on the PAGs they produce. An immunolocalization experiment was carried out in bovine placenta with antibodies against PAG1 and PAG11. In those experiments, they observed clear binucleated trophoblast immunolocalization, but with little colocalization of the staining.

In contrast to the range of PAG expression patterns observed in cattle (and other ruminants), expression of PAGs in swine is more uniform (Szafranska et al. 1995). The porcine trophoblasts stain strongly with PAG antibodies (Whitworth et al. 2010). In another report, the immunolocalization was disproportionately restricted to the microvillar junction rather than to the trophoblasts themselves (Wooding et al. 2005).

The control of PAG gene transcription by the placenta is poorly understood. The regulatory regions immediately upstream of the transcription start sites for each gene are relatively conserved across the family and these regions contain some putative transcription factorbinding sites that appear likely to participate in their transcriptional regulation (Szafranska et al. 2001, Telugu et al. 2009). However, none of these regions have been characterized in a systematic way and there is little mechanistic understanding of how PAG gene transcription is regulated.

In summary, the PAGs exhibit a range of different temporal and spatial patterns of expression throughout pregnancy. As a group, the ancient PAGs are usually detectable earlier in development (authors' unpublished data) and generally at greater abundance compared with the modern PAGs (Touzard et al. 2013). The message profiles of individual PAGs can differ substantially from one another; some are elevated early in pregnancy, while others do not become abundant until later (Patel et al. 2004b, Telugu et al. 2009, Touzard et al. 2013). A further level of complexity arises from the fact that ruminant PAGs vary in their cell-specific expression (mononucleated vs binucleated trophoblast giant cells) and in the location(s) in which they accumulate after secretion. In light of the complex nature of their expression by the placenta, the potential functional roles that the PAGs might play during pregnancy are likely to encompass a number of possibilities. Some of those are discussed in the next section.

\section{Possible functions of the PAGs \\ Roles for PAGs released at the microvillar junction}

Despite many years of study, the role that the PAGs play during pregnancy is unclear. However, one can speculate about their functions based on their expression patterns by the placenta as well as their proteolytic activity, if any. For example, Wooding et al. (2005) noted that some PAGs, such as bovine PAG2 and porcine PAG2, accumulate extensively at the placenta-uterine interface. Both of these PAGs are known to possess proteolytic activity (Telugu \& Green 2008, Telugu et al. 2010). It seems possible that proteolytically active PAGs present at the interface could process latent growth factors that are known to be present at that location (Munger et al. 1998, Rifkin et al. 1999, Moussad et al. 2002). Indeed, if one assumes that individual PAGs will exhibit distinct substrate specificities, each PAG could be targeting distinct growth factors. Another possibility proposed by Wooding et al. (2005) was that PAGs accumulating at the placenta-uterine interface might play a role in adhesion by acting as bridging molecules. The PAGs possess a peptide/substrate-binding cleft as well as $\mathrm{N}$ - and $\mathrm{O}$-linked carbohydrate side chains (Xie et al. 1991, 1997, Green et al. 1998, Klisch et al. 2008). Conceivably, the binding cleft could bind with a protein, such as an integrin, and the carbohydrates displayed on the PAGs could bind a lectin. Protein binding via the cleft may be possible even for those PAGs that possess proteolytic activity. Similar to most aspartic proteinases, those PAGs that can act as proteinases have maximum activity at relatively low pH (Telugu \& Green 2008, Telugu et al. 2010). If the $\mathrm{pH}$ microenvironment is not low enough to promote proteolytic activity, the substrate-binding cleft could still serve as a docking site for other proteins. In such a scenario, a decline in the $\mathrm{pH}$ of the interface microenvironment (e.g. around parturition) would promote proteolytic activity, which could facilitate the disruption of the connections between trophoblast and uterine epithelia.

\section{Potential roles for PAGs present in the maternal uterine stroma and in maternal blood}

Some other considerations come into play for those PAGs that are produced and secreted by ruminant binucleated giant cells. This group of PAGs forms the basis of a pregnancy test in ruminant ungulates (described in the next section). These PAGs are likely to engage in roles that are distinct from those played by others that accumulate at the interface. Some of the 
binucleated cell-specific PAGs become sequestered in the maternal uterine stroma not far from the area of delivery (Fig. 2A; Wooding et al. 2005). In order for this to occur, these PAGs must have some adhesive capacity, although it is unclear what the nature of that binding might be. As was proposed for those PAGs localized at the placenta-uterine interface, the peptide-binding cleft or glycosylation moieties could participate in the sequestering of the PAGs in the uterine stroma. Regardless of how the localization in the uterine stroma is occurring, their presence places these PAGs in a position to influence maternal physiology, especially the maternal immune system. In fact, there is some experimental evidence suggesting that at least one PAG can influence immune function.

\section{Proposed immunomodulatory actions of PAG1/PSPB}

Both experimental and circumstantial evidence suggest that PAGs may be able to affect immune function in cattle. For example, bovine PAG1/PSPB treatment can decrease hematopoietic cell proliferation (Hoeben et al. 1999) and increase the release of granulocyte chemotactic protein 2 (GCP2) from bovine endometrial cells (Austin et al. 1999). PAGs can also bind relatively well to uterine serpins in vitro (Mathialagan \& Hansen 1996). The uterine serpins have immunomodulatory activities and it is possible that the PAGs could be augmenting such actions (Skopets et al. 1995, Liu et al. 1999, Peltier et al. 2000). Finally, it may be notable that polymorphonuclear neutrophil leukocyte activity and other immune cell activities in periparturient cows are lowest around parturition (Kehrli et al. 1989, Saad et al. 1989, Hansen 2013). Circulating PAGs in cattle increase markedly at term (discussed later in this review). If PAGs possess immunomodulatory or immunosuppressive activities (Dunbar et al. 1990, Hoeben et al. 1999, 2000), they may be contributing directly or indirectly to the observed suppression of immune function around the time of calving.

The mechanism through which these immunomodulatory responses are taking place is unknown. Currently, there is little evidence in the literature to suggest that PAGs are stimulating cell targets via a classical receptor signaling pathway. It seems possible that certain PAGs could be generating ligands via their proteolytic activity, which are responsible for these signals. Another possibility is a direct action upon receptors that are activated by proteolytic cleavage (Fu et al. 2015, Zhao et al. 2014). Finally, a PAG-associated immunomodulatory role may be due to the glycosylation moieties displayed on the PAGs. PAGs purified from mid-gestation placenta possess a major carbohydrate that consisted of a tetra-antennary glycan with bisecting $\mathrm{N}$-acetylglucosamine with terminal $\mathrm{Sd}^{\mathrm{a}}$ antigens (Klisch et al. 2008). This glycan could provide some degree of protection to the placental semi-allograft. For example, cells susceptible to lysis by NK cells can be made resistant to such lysis by increasing the proportion of bisecting $\mathrm{N}$-acetylglucosamine on their surface glycoproteins (Yoshimura et al. 1996).

\section{Proposed luteotrophic actions}

In addition to the putative immunomodulatory actions of $\mathrm{PAG} / \mathrm{PSPB}$, there are experimental results that suggest that PAG/PSPB could have a luteotrophic role in cattle and sheep. For example, PSPB treatment of luteal cells resulted in an increase in measurable prostaglandin $E_{2}$ $\left(\mathrm{PGE}_{2}\right.$; Del Vecchio et al. 1996, Weems et al. 1998a). $\mathrm{PGE}_{2}$ has luteotrophic and anti-luteolytic actions in ruminants. A protein acting as a luteotrophic compound might be expected to cause an increase in progesterone production from luteal cells. Indeed, bovine PSPB administration to luteal cells has been reported to increase progesterone concentration in the conditioned media, although this response has not been observed consistently (Del Vecchio et al. 1995, Weems et al. 1998b). Interestingly, PSPB was able to increase progesterone only in corpora lutea from the estrous cycle (day 14); corpora lutea obtained from day 200 of pregnancy did not exhibit such an increase (Weems et al. 1998a,b).

When administered to cultured endometrium, PSPB produced an increase in $\mathrm{PGE}_{2}$ in the media. This observation was made in cultures of both bovine endometrium and ovine caruncular tissue (Del Vecchio et al. 1990, Weems et al. 2003).

Clearly, there is some experimental support for either an immunomodulatory role or a luteotrophic role for the binucleated trophoblast-specific PAGs. These putative functions (luteotrophic vs immunomodulatory) seem quite distinct from one another and appear difficult to reconcile. The number and diversity of modern PAGs argues against a luteotrophic role for all the members of this group. In other words, it is not clear why the ruminant conceptus would produce large numbers of different luteotrophic proteins when one or a few would suffice. The possibility that PAGs are immunomodulatory or immunosuppressive could explain the conspicuous presence of dozens of PAGs with the peptide-binding capacity expressed at the placenta-uterine interface. As stated earlier in this review, the accumulation of binucleated trophoblast (modern) PAGs in the maternal stroma would position them to potentially influence lymphocyte or PMN leukocyte migration and/or activation. However, if binucleated trophoblast PAGs are indeed immunosuppressive, the biological advantage gained by allowing them to escape into the maternal circulation (and accumulate to high concentrations) is a mystery. In fact, it could have serious consequences for the ability of the mother to fight infections during pregnancy.

One might wonder if there is a way to reconcile the apparent discrepancy between these experimental 
observations. A likely possibility is that the modern PAGs actually represent a multifunctional group. If this is the case, then the potential that PAGs could act as luteotrophic compounds to increase $\mathrm{PGE}_{2}$ production from endometrium, $\mathrm{CL}$, and/or placenta is distinctly possible because a specific PAG could serve in such a capacity. It is also likely that the PAG1/PSPB preparations used in these studies may have contained multiple PAGs (Butler et al. 1982, Zoli et al. 1991), which could explain how different research laboratories could obtain differing results using similar isolates. Another possibility is that the two proposed models for PAG function are actually looking at the same basic phenomenon. The proluteotrophic hypothesis is based on the ability of PAG to increase $\mathrm{PGE}_{2}$ (Weems et al. 2003). It is worth noting that $\mathrm{PGE}_{2}$ also possesses potent immunosuppressive activity and can inhibit proliferation of T lymphocytes at nanomolar concentrations (Low \& Hansen 1988).

Therefore, it is apparent that a great deal of more experimental work needs to be carried out to better define the function of the PAGs in ungulate pregnancy. In light of the diversity of PAGs within and across species, it seems likely that PAGs play multiple roles related to placental development and function in the Cetartiodactyla.

\section{PAGs as circulating markers to study placental function and as tools for reproductive management of livestock}

Although no clear function of PAGs has been identified, their accumulation in maternal blood of ruminant ungulates has become a useful tool for monitoring pregnancy. Indeed, majority of the published works on PAGs have focused on the development of a reliable tool for diagnosing pregnancy in ruminant species, including cattle, sheep, goats, bison, moose, and elk (Sasser et al. 1986, Wood et al. 1986, Ruder et al. 1988, Green et al. 1998, Willard et al. 1999, Szafranska et al. 2006).

Identifying the presence of an embryo as early as possible is of considerable commercial interest to cattle producers - particularly those in the dairy industry (LeBlanc 2013). Consequently, there have been many attempts to identify pregnancy markers for use in cattle. Some examples include the following: early conception factor that becomes elevated by day 2 post-insemination in cattle (Cordoba et al. 2001, Ghaffari Laleh et al. 2008); interferon-stimulated genes increase in circulating leukocytes between days 16 to 20 post-insemination (Gifford et al. 2007, Green et al. 2010); progesterone concentration in milk can be used to distinguish between pregnant and nonpregnant cattle between days 20 to 24 post-insemination (Nebel 1988); and finally, circulating PAGs can reliably identify pregnant cattle by day 30 , with some assays able to measure PAGs even a few days earlier (beginning at approximately day 25 post-insemination) (Sasser et al. 1986, Zoli et al. 1992, Green et al. 2005).

PAG1 (PSPB) has been the primary PAG of interest for pregnancy diagnosis in cattle (Sasser et al. 1986, Zoli et al. 1992), although more recently developed assays may be recognizing PAGs that are immunologically distinct from PAG1 (Perényi et al. 2002, Green et al. 2005). Various PAG/PSPB assays have been commercialized and there are now companies that provide pregnancy diagnosis services based on PAG detection for cattle, sheep, goats, bison, and wildlife. Overall, the PAG assays are generally reliable and their accuracy in detecting bovine PAGs in maternal blood and milk has been reported to range from 93 to $96 \%$ (Silva et al. 2007, Pohler et al. 2013). Even so, the tests have shown spurious results in certain subsets of animals on occasion. For example, pregnant cows with a viable embryo (evidence of a heart beat), which do not have detectable circulating concentrations of immunoreactive PAGs (Pohler et al. 2013), have been identified by realtime ultrasonography. Currently, it is not known whether the fetuses in these pregnant cows are producing PAGs that are unable to accumulate sufficiently in the maternal circulation or whether the PAG antibodies used in the assay cannot detect PAGs from those particular animals. Despite many years of study, it is not fully understood as to which PAGs are most abundant in the maternal circulation during pregnancy or which circulating PAGs are most readily detected by the antibodies employed in the current assays. There are also examples of PAG immunoreactivity found in nonpregnant females and male animals, although these putatively 'positive' samples represent only a minor proportion of tested animals (Zoli et al. 1992, Green et al. 2005). At present, the source of this immunoreactivity in certain nonpregnant animals is not known.

Some notable features of circulating bovine PAGs relate to their rather high concentration $(1-5 \mu \mathrm{g} / \mathrm{ml})$ immediately before parturition and their relatively long half-life (8-10 days) in the post partum period (Sasser et al. 1989, Zoli et al. 1992, Kiracofe et al. 1993, Melo de Sousa et al. 2003). Interestingly, the measurable half-life appears to differ depending on when during pregnancy it is measured. The different PAG antibodies and assay platforms may also explain why published reports sometimes give rise to different results regarding PAG concentrations and half-life. In a few similar studies, circulating PAGs were monitored following induced late embryonic abortion in pregnant heifers (Szenci et al. 2003, Giordano et al. 2012, Pohler et al. 2013). The estimated half-life ranged from 2.7 to 3.9 days (Szenci et al. 2003) to $35.8 \pm 21.9 \mathrm{~h}$ (mean \pm s.D.) (Pohler et al. 2013). These differences in the half-life of PAGs are probably due to detection of different members of the PAG family or to the detection of differentially glycosylated variants of the same PAG family members during pregnancy or the post partum period. 

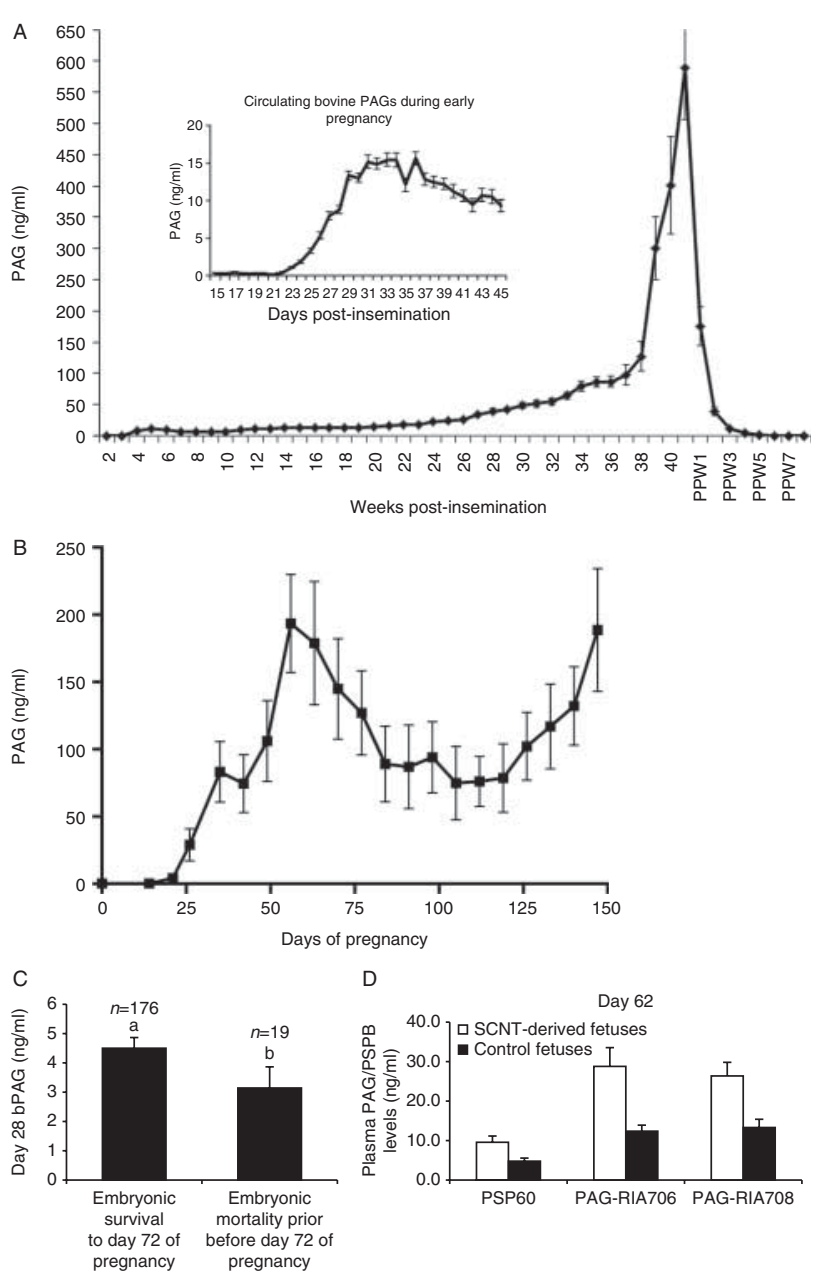

Figure 3 Circulating PAG profiles and illustrations of how circulating PAGs are affected by abnormal placental function. (A) Representative PAG serum profile as is typically observed in domestic cattle (Bos taurus). Circulating PAGs begin to rise rapidly in maternal blood during the 4th week of pregnancy. The levels decline at $\sim 8-10$ weeks and then begin to rise steadily through the rest of pregnancy. Approximately 1-2 weeks before parturition, circulating PAGs increase dramatically once again to peak around the time of calving. The inset picture is shown to better illustrate the rapid elevation in the levels of circulating PAGs early in bovine pregnancy. These results are compiled from values reported previously (Green et al. 2005). (B) Representative PAG serum profile as is typically observed in domestic sheep (Ovis aries). Circulating PAGs in small ruminants can exhibit pronounced biphasic profiles. Typically, there are two peaks during the course of pregnancy; one rise occurs around the end of the first trimester and the second one is at term. Profile values are compiled from results reported previously (Egen et al. 2009). (C) Serum concentrations of PAG in samples collected on day 28 from cattle with a viable embryo. Those animals that maintained a pregnancy beyond day 72 of gestation had significantly elevated levels of PAG compared with those animals that subsequently lost the pregnancy after day 28 but before day 72. Image is modified from Pohler et al. (2013). (D) Circulating PAG concentrations from surrogate cows (at day 62 of gestation) that received either SCNT-derived embryos or control embryos. PAG/PSPB concentrations measured in three different assay platforms were significantly elevated in those animals carrying SCNT-derived embryos. The labels along the bottom indicated the different PAG antibody RIAs used to quantify PAG/PSPB. The image is modified from one in Constant et al. (2011).
As one might predict, the persistence of PAGs well into the post partum period can limit the use of PAGs as a pregnancy detection tool due to the potential of false positives if animals are successfully rebred soon after calving. Therefore, efforts have been made to selectively detect circulating PAGs that are relatively less abundant at term or that have a shorter half-life compared with PAG1 (Green et al. 2005). Those efforts have had some limited success; a monoclonal-based ELISA has been established that targets PAGs with a relatively shorter half-life (4.3 days), while still permitting pregnancy diagnosis by day 28 of gestation (Fig. 3) (Green et al. 2005). Although there was still a substantial rise of circulating PAGs at term, PAGs were undetectable in maternal blood by 8 weeks post partum in $95 \%$ of the cows that were tested (Green et al. 2005). Consequently, measuring PAGs that have a shorter halflife than bovine PAG1 helped overcome some of the difficulty that arises from the persistence of PAG far into the post partum period.

In addition to serving as an accurate tool for diagnosing pregnancy in ruminants, PAGs may also serve as a marker for monitoring embryonic/fetal viability and placental function. For example, beef cows that successfully carried a pregnancy past day 72 of gestation had higher concentrations of PAGs on day 28 compared with cows that exhibited late embryonic/fetal mortality sometime between days 28 to 72 (Fig. 3C; Pohler et al. 2013). Furthermore, circulating concentrations of PAGs were decreased on day 41 post-insemination in beef cows that experienced embryonic/fetal loss compared with cows that maintained pregnancy (Perry et al. 2005). In the preceding studies, all cows were assessed by ultrasound to have a normal embryo with a heartbeat on day 28 of gestation. Similar results have been reported in dairy cows (Humblot et al. 1988, Breukelman et al. 2012) and sheep (Wallace et al. 1997). Collectively, these data suggest that measurement of circulating PAGs in ruminant ungulates may serve as a useful animal management tool for identifying pregnant animals that are likely to undergo loss of the fetus.

In the examples provided in the previous paragraph, circulating PAGs were found to be lower in pregnant animals more likely to abort the pregnancy - probably due to placentas that are compromised in some manners. However, there are situations in which altered placental function results in an elevation in the levels of circulating PAGs. In cattle, the use of somatic cell nuclear transfer (SCNT) usually results in a higher incidence of embryonic/fetal loss throughout gestation. These losses are generally thought to be the result of abnormal placental development, as reflected by a decrease in placentome numbers (Hill et al. 2000, Lee et al. 2004). Hashizume et al. (2002) demonstrated that mRNAs for placental lactogen and PAGs were reduced in SCNTderived pregnancies compared with control pregnancies. Somewhat unexpectedly, circulating concentrations of 
PAGs have been shown to be greater in recipient cows receiving SCNT-derived embryos compared with control embryos (Chavatte-Palmer et al. 2006, Constant et al. 2011). Furthermore, PAG concentrations were higher in recipient cows at day 35 (Hill et al. 2000) and day 50 (Heyman et al. 2002) of gestation for animals that received an SCNT embryo that subsequently aborted during the first trimester compared with cows that maintained a pregnancy. These observations may reflect some of the structural alterations at the placenta-uterine interface that have been described in SCNT pregnancies; such changes may lead to an increased opportunity for uptake of trophoblast products by maternal epithelia (Pereira et al. 2013). Constant et al. (2011) reported that the increase in maternal concentrations of PAGs in cows that received an SCNT embryo was likely not due to an increased number of binucleated cells or an increased synthetic activity of binucleated cells; they predicted that it was most probably due to an augmentation in the half-life of the PAGs detected in the assay.

Briefly, the profiles of PAGs in the maternal circulation can be affected by a number of factors. In addition to those described in this review, circulating concentrations of PAGs are also influenced by other factors such as breed, weight, parity status of the dam, fetal sex, fetal number, fetal birth weight as well as the assay platform/antibodies used to perform the PAG measurements themselves (Patel et al. 1997, Echternkamp et al. 2006, Lobago et al. 2009, Mercadante et al. 2013). Despite the often perplexing differences observed in circulating PAGs, the measurement of these proteins in maternal blood and milk is becoming a common practice for pregnancy detection in many ruminant production systems. It also seems likely that PAGs will continue to be used as biochemical markers to better understand the reproductive physiology as well as finding use as diagnostic tools for making animal management decisions in livestock and captive animal programs.

\section{Summary}

The PAGs are major secretory products of the artiodactyl placenta that have been the subject of extensive investigation for more than three decades. However, many aspects of these proteins remain a mystery. The large number of PAG gene products, which exhibit a range of temporal and spatial expression patterns, suggests that they may play a number of functional roles at the placenta-uterine interface. The fact that many appear to be capable of performing proteolytic activity, while some are unlikely to act in this way, further adds to their complexity. The accumulation of some PAGs in maternal blood (in the Ruminantia) opens up the possibility of actions directly upon the maternal system (e.g. ovaries, etc.). Clearly, a great deal of work remains to be carried out in order to achieve a real understanding of these molecules. The PAGs present in different suborders within the Cetartiodactyla (e.g. Suidae, Cetacea, and Ruminantia) are distinct enough from one another that there are no obvious orthologous members between these groups (Fig. 1) (Hughes et al. 2000). Presumably, the PAGs are filling niches unique to the (syn)epitheliochorial placental forms represented in this phylogenetic order. Future insights gained about these proteins will correspondingly provide new insights into how cetartiodactyl placentas have become refined since the order arose.

\section{Declaration of interest}

J A Green is listed as an inventor on patents related to the detection of PAGs in pregnant females. R M Wallace, K G Pohler, and M F Smith have no conflicts of interest that could be perceived as prejudicing the impartiality of the review.

\section{Funding}

Financial support during the drafting of this review was provided by the Food for the 21 st Century Animal Reproductive Biology Cluster and the Division of Animal Sciences at the University of Missouri.

\section{References}

Austin KJ, King CP, Vierk JE, Sasser RG \& Hansen TR 1999 Pregnancy-specific protein $\mathrm{B}$ induces release of an alpha chemokine in bovine endometrium. Endocrinology 140 542-545. (doi:10.1210/endo.140.1.6608)

Barbato O, Sousa NM, Klisch K, Clerget E, Debenedetti A, Barile VL, Malfatti A \& Beckers JF 2008 Isolation of new pregnancy-associated glycoproteins from water buffalo (Bubalus bubalis) placenta by Vicia villosa affinity chromatography. Research in Veterinary Science 85 457-466. (doi:10.1016/j.rvsc.2008.01.004)

Bériot M, Tchimbou AF, Barbato O, Beckers J-F \& de Sousa NM 2014 Identification of pregnancy-associated glycoproteins and $\alpha$-fetoprotein in fallow deer (Dama dama) placenta. Acta Veterinaria Scandinavica 564. (doi:10.1186/1751-0147-56-4)

Brandt GA, Parks TE, Killian G, Ealy AD \& Green JA 2007 A cloning and expression analysis of pregnancy-associated glycoproteins expressed in trophoblasts of the white-tail deer placenta. Molecular Reproduction and Development 74 1355-1362. (doi:10.1002/mrd.20669)

Breukelman SP, Perényi Z, Taverne MA, Jonker H, van der Weijden GC, Vos PL, de Ruigh L, Dieleman SJ, Beckers JF \& Szenci O 2012 Characterisation of pregnancy losses after embryo transfer by measuring plasma progesterone and bovine pregnancy-associated glycoprotein-1 concentrations. Veterinary Journal 194 71-76. (doi:10.1016/j.tvjl.2012. 02.020)

Butler JE, Hamilton WC, Sasser RG, Ruder CA, Hass GM \& Williams RJ 1982 Detection and partial characterization of two bovine pregnancyspecific proteins. Biology of Reproduction 26 925-933. (doi:10.1095/ biolreprod26.5.925)

Chavatte-Palmer P, de Sousa N, Laigre P, Camous S, Ponter AA, Beckers JF \& Heyman Y 2006 Ultrasound fetal measurements and pregnancy associated glycoprotein secretion in early pregnancy in cattle recipients carrying somatic clones. Theriogenology 66 829-840. (doi:10.1016/j. theriogenology.2006.01.061)

Constant F, Camous S, Chavatte-Palmer P, Heyman Y, de Sousa N, Richard C, Beckers JF \& Guillomot M 2011 Altered secretion of pregnancy-associated glycoproteins during gestation in bovine somatic clones. Theriogenology 76 1006-1021. (doi:10.1016/j.theriogenology. 2011.04.029) 
Cordoba MC, Sartori R \& Fricke PM 2001 Assessment of a commercially available early conception factor (ECF) test for determining pregnancy status of dairy cattle. Journal of Dairy Science 84 1884-1889. (doi:10.3168/jds.S0022-0302(01)74629-2)

Davies DR 1990 The structure and function of the aspartic proteinases. Annual Review of Biophysics and Biophysical Chemistry 19 189-215. (doi:10.1146/annurev.bb.19.060190.001201)

Del Vecchio RP, Sasser RG \& Randel RD 1990 Effect of pregnancy-specific protein $\mathrm{B}$ on prostaglandin $\mathrm{F} 2 \alpha$ and prostaglandin E2 release by day 16-perifused bovine endometrial tissue. Prostaglandins 40 271-282. (doi:10.1016/0090-6980(90)90015-N)

Del Vecchio RP, Sutherland WD \& Sasser RG 1995 Effect of pregnancyspecific protein B on luteal cell progesterone, prostaglandin, and oxytocin production during two stages of the bovine estrous cycle. Journal of Animal Science 73 2662-2668.

Del Vecchio RP, Sutherland WD \& Sasser RG 1996 Bovine luteal cell production in vitro of prostaglandin E2, oxytocin and progesterone in response to pregnancy-specific protein B and prostaglandin F2 $\alpha$. Journal of Reproduction and Fertility 107 131-136. (doi:10.1530/jrf.0.1070131)

Duello TM, Byatt JC \& Bremel RD 1986 Immunohistochemical localization of placental lactogen in binucleate cells of bovine placentomes. Endocrinology 119 1351-1355. (doi:10.1210/endo-119-3-1351)

Dunbar MM, Wong TS, Ruder-Montgomery CA, Chew CA \& Sasser RG 1990 Partial characterization of the immunosuppressive properties of pregnancy-specific protein B (PSPB). Theriogenology 33 (Suppl 1) 220. (doi:10.1016/0093-691X(90)90644-9)

Dunn BM 2002 Structure and mechanism of the pepsin-like family of aspartic peptidases. Chemical Reviews 102 4431-4458. (doi:10.1021/ cr010167q)

Echternkamp SE, Vonnahme KA, Green JA \& Ford SP 2006 Increased vascular endothelial growth factor and pregnancy-associated glycoproteins, but not insulin-like growth factor-I, in maternal blood of cows gestating twin fetuses. Journal of Animal Science 84 2057-2064. (doi:10. 2527/jas.2005-714)

Egen TE, Ealy AD, Landon LA, Roberts RM \& Green JA 2009 Autoimmunization of ewes against pregnancy-associated glycoproteins does not interfere with the establishment and maintenance of pregnancy. Animal 3 850-857. (doi:10.1017/S1751731109004145)

Faria TN, Deb S, Kwok SC, Talamantes F \& Soares MJ 1990 Ontogeny of placental lactogen-I and placental lactogen-II expression in the developing rat placenta. Developmental Biology 141 279-291. (doi:10.1016/0012-1606(90)90384-U)

Fu Q, Cheng J, Gao Y, Zhang Y, Chen X \& Xie J 2015 Proteaseactivated receptor 4: a critical participator in inflammatory response. Inflammation. In press. (doi:10.1007/s10753-014-9999-6)

Garbayo JM, Green JA, Mannekin M, Beckers J-F, Kiesling DO, Ealy AD \& Roberts RM 2000 Caprine pregnancy-associated glycoproteins (PAG): their cloning, expression and evolutionary relationship to other PAG. Molecular Reproduction and Development 57 311-322. (doi:10.1002/ 1098-2795(200012)57:4<311::AID-MRD2 > 3.0.CO;2-F)

Ghaffari Laleh V, Ghaffari Laleh R, Pirany N \& Moghadaszadeh Ahrabi M 2008 Measurement of EPF for detection of cow pregnancy using rosette inhibition test. Theriogenology 70 105-107. (doi:10.1016/j.theriogenology.2008.02.003)

Gifford CA, Racicot K, Clark DS, Austin KJ, Hansen TR, Lucy MC, Davies CJ \& Ott TL 2007 Regulation of Interferon-stimulated genes in peripheral blood leukocytes in pregnant and bred, nonpregnant dairy cows. Journal of Dairy Science 90 274-280. (doi:10.3168/jds.S0022-0302 (07)72628-0)

Giordano JO, Guenther JN, Lopes G Jr \& Fricke PM 2012 Changes in serum pregnancy-associated glycoprotein, pregnancy-specific protein $B$, and progesterone concentrations before and after induction of pregnancy loss in lactating dairy cows. Journal of Dairy Science 95 683-697. (doi:10.3168/jds.2011-4609)

Green JA, Xie S \& Roberts RM 1998 Pepsin-related molecules secreted by trophoblast. Reviews of Reproduction 3 62-69. (doi:10.1530/ror.0. 0030062)

Green JA, Xie S, Quan X, Bao B, Gan X, Mathialagan N, Beckers J-F \& Roberts RM 2000 Pregnancy-associated bovine and ovine glycoproteins exhibit spatially and temporally distinct expression patterns during pregnancy. Biology of Reproduction 62 1624-1631. (doi:10.1095/ biolreprod62.6.1624)
Green JA, Parks TE, Avalle MP, Telugu BP, McLain AL, Peterson AJ, McMillan W, Mathialagan N, Xie S, Hook RR et al. 2005 The establishment of an ELISA for the detection of pregnancy-associated glycoproteins (PAGs) in the serum of pregnant cows and heifers. Theriogenology 63 1481-1503. (doi:10.1016/j.theriogenology.2004.07. 011)

Green JC, Okamura CS, Poock SE \& Lucy MC 2010 Measurement of interferon-tau (IFN- $\tau$ ) stimulated gene expression in blood leukocytes for pregnancy diagnosis within 18-20d after insemination in dairy cattle. Animal Reproduction Science 121 24-33. (doi:10.1016/j.anireprosci. 2010.05.010)

Guruprasad K, Blundell TL, Xie S, Green J, Szafranska B, Nagel RJ, McDowell K, Baker CB \& Roberts RM 1996 Comparative modelling and analysis of amino acid substitutions suggests that the family of pregnancy-associated glycoproteins includes both active and inactive aspartic proteinases. Protein Engineering 9 849-856. (doi:10.1093/ protein/9.10.849)

Hansen PJ 2013 Physiology and Endocrinology Symposium: maternal immunological adjustments to pregnancy and parturition in ruminants and possible implications for postpartum uterine health: is there a prepartum-postpartum nexus? Journal of Animal Science 91 1639-1649. (doi:10.2527/jas.2012-5934)

Hashizume K, Ishiwata H, Kizaki K, Yamada O, Takahashi T, Imai K, Patel O, Akagi S, Shimizu M, Takahashi S et al. 2002 Implantation and placental development in somatic cell clone recipient cows. Cloning and Stem Cells 4 197-209. (doi:10.1089/15362300260339485)

Heyman Y, Chavatte-Palmer P, LeBourhis D, Camous S, Vignon X \& Renard J 2002 Frequency and occurrence of late-gestation losses from cattle cloned embryos. Biology of Reproduction 66 6-13. (doi:10.1095/ biolreprod66.1.6)

Hill JR, Burghardt RC, Jones K, Long CR, Looney CR, Shin T, Spencer TE, Thompson JA, Winger QA \& Westhusin ME 2000 Evidence for placental abnormality as the major cause of mortality in first-trimester somatic cell cloned bovine fetuses. Biology of Reproduction 63 1787-1794. (doi:10.1095/biolreprod63.6.1787)

Hoeben D, Burvenich C, Massart-Leen AM, Lenjou M, Nijs G, Van Bockstaele D \& Beckers JF 1999 In vitro effect of ketone bodies, glucocorticosteroids and bovine pregnancy-associated glycoprotein on cultures of bone marrow progenitor cells of cows and calves. Veterinary Immunology and Immunopathology 68 229-240. (doi:10.1016/S01652427(99)00031-8)

Hoeben D, Monfardini E, Opsomer G, Burvenich C, Dosogne H, De Kruif A \& Beckers JF 2000 Chemiluminescence of bovine polymorphonuclear leucocytes during the periparturient period and relation with metabolic markers and bovine pregnancy-associated glycoprotein. Journal of Dairy Research 67 249-259. (doi:10.1017/S00220299 00004052)

Hughes AL, Green JA, Garbayo JM \& Roberts RM 2000 Adaptive diversification within a large family of recently duplicated, placentally-expressed genes. PNAS 97 3319-3323. (doi:10.1073/pnas. 97.7.3319)

Hughes AL, Green JA, Piontkivska H \& Roberts RM 2003 Aspartic proteinase phylogeny and the origin of pregnancy-associated glycoproteins. Molecular Biology and Evolution 20 1940-1945. (doi:10.1093/ molbev/msg217)

Humblot P, Camous S, Martal J, Charlery J, Jeanguyot N, Thibier M \& Sasser RG 1988 Diagnosis of pregnancy by radioimmunoassay of a pregnancy-specific protein in the plasma of dairy cows. Theriogenology 30 257-268. (doi:10.1016/0093-691X(88)90175-6)

Kehrli ME, Nonnecke BJ \& Roth JA 1989 Alterations in bovine peripheral blood neutrophil function during the periparturient period. American Journal of Veterinary Research 50 207-214.

Kimura J, Sasaki M, Endo H \& Fukuta K 2004 Anatomical and histological characterization of the female reproductive organs of mouse deer (Tragulidae). Placenta 25 705-711. (doi:10.1016/j.placenta.2004.02.009)

King GJ 1993 Comparative placentation in ungulates. Journal of Experimental Zoology 266 588-602. (doi:10.1002/jez.1402660609)

Kiracofe GH, Wright JM, Schalles RR, Ruder CA, Parish S \& Sasser RG 1993 Pregnancy-specific protein B in serum of postpartum beef cows. Journal of Animal Science 71 2199-2205.

Klisch K, Jeanrond E, Pang P-C, Pich A, Schuler G, Dantzer V, Kowalewski MP \& Dell A 2008 A tetraantennary glycan with bisecting 
$\mathrm{N}$-acetylglucosamine and the Sda antigen is the predominant $\mathrm{N}$-glycan on bovine pregnancy-associated glycoproteins. Glycobiology 18 42-52. (doi:10.1093/glycob/cwm113)

LeBlanc SJ 2013 Short communication: Field evaluation of a pregnancy confirmation test using milk samples in dairy cows. Journal of Dairy Science 96 2345-2348. (doi:10.3168/jds.2012-6414)

Lee CS, Gogolin-Ewens K, White TR \& Brandon MR 1985 Studies on the distribution of binucleate cells in the placenta of sheep with a monoclonal antibody SBU-3. Journal of Anatomy 140 565-576.

Lee RS, Peterson AJ, Donnison MJ, Ravelich S, Ledgard AM, Li N, Oliver JE, Miller AL, Tucker FC, Breier B et al. 2004 Cloned cattle fetuses with the same nuclear genetics are more variable than contemporary half-siblings resulting from artificial insemination and exhibit fetal and placental growth deregulation even in the first trimester. Biology of Reproduction 70 1-11. (doi:10.1095/biolreprod.103.020982)

Liu WJ, Peltier MR \& Hansen PJ 1999 Binding of ovine uterine serpin to lymphocytes. American Journal of Reproductive Immunology $\mathbf{4 1}$ 428-432. (doi:10.1111/j.1600-0897.1999.tb00458.x)

Lobago F, Bekana M, Gustafsson H, Beckers JF, Yohannes G, Aster Y \& Kindahl H 2009 Serum profiles of pregnancy-associated glycoprotein, oestrone sulphate and progesterone during gestation and some factors influencing the profiles in Ethiopian Borana and crossbred cattle. Reproduction in Domestic Animals 44 685-692. (doi:10.1111/j.14390531.2007.01049.x)

Low BG \& Hansen PJ 1988 Immunosuppressive actions of steroids and prostaglandins secreted by the placenta and uterus of the cow and sheep. American Journal of Reproductive Immunology and Microbiology 18 71-75.

Majewska M, Panasiewicz G, Majewski M \& Szafrańska B 2006 Localization of chorionic pregnancy-associated glycoprotein family in the pig. Reproductive Biology 6 205-230.

Majewska M, Panasiewicz G \& Szafranska B 2011 Pregnancy-associated glycoprotein (PAG) family localized in chorionic cells within the epitheliochorial/diffuse placenta of the alpaca (Lama pacos). Acta Histochemica 113 570-577. (doi:10.1016/j.acthis.2010.06.002)

Mathialagan N \& Hansen TR 1996 Pepsin-inhibitory activity of the uterine serpins. PNAS 93 13653-13658. (doi:10.1073/pnas.93.24.13653)

Melo de Sousa N, Zongo M, Pitala W, Boly H, Sawadogo L, Sanon M, Ricardo de Figueiredo J, Goncalves PBD, El Amiri B, Perenyi Z et al. 2003 Pregnancy-associated glycoprotein concentrations during pregnancy and the postpartum period in Azawak Zebu cattle. Theriogenology 59 1131-1142. (doi:10.1016/S0093-691X(02)01160-3)

Mercadante PM, Waters KM, Mercadante VR, Lamb GC, Elzo MA, Johnson SE, Rae DO, Yelich JV \& Ealy AD 2013 Subspecies differences in early fetal development and plasma pregnancy-associated glycoprotein concentrations in cattle. Journal of Animal Science 91 3693-3701. (doi:10.2527/jas.2012-6130)

Mialon MM, Camous S, Renand G, Martal J \& Menissier F 1993 Peripheral concentrations of a $60-\mathrm{kDa}$ pregnancy serum protein during gestation and after calving and in relationship to embryonic mortality in cattle. Reproduction, Nutrition, Development 33 269-282. (doi:10.1051/ rnd:19930309)

Mialon MM, Renand G, Camous S, Martal J \& Menissier F 1994 Detection of pregnancy by radioimmunoassay of a pregnancy serum protein (PSP60) in cattle. Reproduction, Nutrition, Development 34 65-72. (doi:10.1051/rnd:19940107)

Moussad EE, Rageh MA, Wilson AK, Geisert RD \& Brigstock DR 2002 Temporal and spatial expression of connective tissue growth factor (CCN2; CTGF) and transforming growth factor beta type 1 (TGF- $\beta 1$ ) at the utero-placental interface during early pregnancy in the pig. Journal of Clinical Pathology: Molecular Pathology 55 186-192. (doi:10.1136/ mp.55.3.186)

Munger JS, Harpel JG, Giancotti FG \& Rifkin DB 1998 Interactions between growth factors and integrins: latent forms of transforming growth factor-beta are ligands for the integrin $\alpha \mathrm{v} \beta 1$. Molecular Biology of the Cell 9 2627-2638. (doi:10.1091/mbc.9.9.2627)

Nebel RL 1988 On-farm milk progesterone tests. Journal of Dairy Science 71 1682-1690. (doi:10.3168/jds.S0022-0302(88)79733-7)

Patel O, Sulon J, Beckers J, Takahashi T, Hirako M, Sasaki N \& Domeki I 1997 Plasma bovine pregnancy-associated glycoprotein concentrations throughout gestation in relationship to fetal number in the cow. European Journal of Endocrinology 137 423-428. (doi:10.1530/eje.0.1370423)
Patel OV, Yamada O, Kizaki K, Todoroki J, Takahashi T, Imai K, Schuler LA \& Hashizume K 2004a Temporospatial expression of placental lactogen and prolactin-related protein-1 genes in the bovine placenta and uterus during pregnancy. Molecular Reproduction and Development 69 146-152. (doi:10.1002/mrd.20119)

Patel OV, Yamada O, Kizaki K, Takahashi T, Imai K \& Hashizume K 2004b Quantitative analysis throughout pregnancy of placentomal and interplacentomal expression of pregnancy-associated glycoproteins-1 and -9 in the cow. Molecular Reproduction and Development 67 257-263. (doi:10.1002/mrd.20017)

Peltier MR, Liu WJ \& Hansen PJ 2000 Regulation of lymphocyte proliferation by uterine serpin: interleukin-2 mRNA production, CD25 expression and responsiveness to interleukin-2. Proceedings of the Society for Experimental Biology and Medicine 223 75-81. (doi:10.1046/j.1525-1373.2000.22310.x)

Pereira FTV, Oliveira LJ, Barreto RdSN, Mess A, Perecin F, Bressan FF, Mesquita LG, Miglino MA, Pimentel JR, Neto PF et al. 2013 Fetalmaternal interactions in the synepitheliochorial placenta using the eGFP cloned cattle model. PLoS ONE 8 e64399. (doi:10.1371/journal.pone. 0064399)

Perényi ZS, Szenci O, Sulon J, Drion PV \& Beckers JF 2002 Comparison of the ability of three radioimmunoassay to detect pregnancy-associated glycoproteins in bovine plasma. Reproduction in Domestic Animals 37 100-104.

Perry GA, Smith MF, Lucy MC, Green JA, Parks TE, MacNeil MD, Roberts AJ \& Geary TW 2005 Relationship between follicle size at insemination and pregnancy success. PNAS 102 5268-5273. (doi:10. 1073/pnas.0501700102)

Pohler KG, Geary TW, Johnson CL, Atkins JA, Jinks EM, Busch DC, Green JA, MacNeil MD \& Smith MF 2013 Circulating bovine pregnancy associated glycoproteins are associated with late embryonic/fetal survival but not ovulatory follicle size in suckled beef cows. Journal of Animal Science 91 4158-4167. (doi:10.2527/jas. 2013-6348)

Rifkin DB, Mazzieri R, Munger JS, Noguera I \& Sung J 1999 Proteolytic control of growth factor availability. APMIS: Acta Pathologica, Microbiologica, et Immunologica Scandinavica 107 80-85. (doi:10.1111/j. 1699-0463.1999.tb01529.x)

Ruder CA, Stellflug JN, Dahmen JJ \& Sasser RG 1988 Detection of pregnancy in sheep by radioimmunoassay of sera for pregnancy-specific protein B. Theriogenology 29 905-912. (doi:10.1016/0093-691X (88)90227-0)

Saad AM, Concha C \& Astrom G 1989 Alterations in neutrophil phagocytosis and lymphocyte blastogenesis in dairy cows around parturition. Journal of Veterinary Medicine. B, Infectious Diseases and Veterinary Public Health 36 337-345. (doi:10.1111/j.1439-0450.1989. tb00612.x)

Sasser RG, Ruder CA, Ivani KA, Butler JE \& Hamilton WC 1986 Detection of pregnancy by radioimmunoassay of a novel pregnancy-specific protein in serum of cows and a profile of serum concentrations during gestation. Biology of Reproduction 35 936-942. (doi:10.1095/biolreprod35.4.936)

Sasser RG, Crock J \& Ruder-Montgomery CA 1989 Characteristics of pregnancy-specific protein B in cattle. Journal of Reproduction and Fertility. Supplement 37 109-113.

Silva E, Sterry RA, Kolb D, Mathialagan N, McGrath MF, Ballam JM \& Fricke PM 2007 Accuracy of a pregnancy-associated glycoprotein ELISA to determine pregnancy status of lactating dairy cows twenty-seven days after timed artificial insemination. Journal of Dairy Science $\mathbf{9 0}$ 4612-4622. (doi:10.3168/jds.2007-0276)

Skopets B, Liu WJ \& Hansen PJ 1995 Effects of endometrial serpin-like proteins on immune responses in sheep. American Journal of Reproductive Immunology 33 86-93. (doi:10.1111/j.1600-0897.1995.tb01143.x)

Szafranska B, Xie S, Green J \& Roberts RM 1995 Porcine pregnancyassociated glycoproteins: new members of the aspartic proteinase gene family expressed in trophectoderm. Biology of Reproduction 53 21-28. (doi:10.1095/biolreprod53.1.21)

Szafranska B, Miura R, Ghosh D, Ezashi T, Xie S, Roberts RM \& Green JA 2001 The gene for porcine pregnancy-associated glycoprotein 2 (poPAG2): its structural organization and analysis of its promoter. Molecular Reproduction and Development 66 137-146. (doi:10.1002/ mrd.1070) 
Szafranska B, Panasiewicz G \& Majewska M 2006 Biodiversity of multiple pregnancy-associated glycoprotein (PAG) family: gene cloning and chorionic protein purification in domestic and wild eutherians (Placentalia) - a review. Reproduction, Nutrition, Development $\mathbf{4 6}$ 481-502. (doi:10.1051/rnd:2006034)

Szenci O, Beckers JF, Sulon J, Bevers MM, Börzsönyi L, Fodor L, Kovács $F$ \& Taverne MA 2003 Effect of induction of late embryonic mortality on plasma profiles of pregnancy associated glycoprotein 1 in heifers. Veterinary Journal $\mathbf{1 6 5}$ 307-313. (doi:10.1016/S10900233(02)00180-6)

Tamura K, Stecher G, Peterson D, Filipski A \& Kumar S 2013 MEGA6: Molecular Evolutionary Genetics Analysis version 6.0. Molecular Biology and Evolution 30 2725-2729. (doi:10.1093/molbev/mst197)

Telugu BP \& Green JA 2008 Characterization of the peptidase activity of recombinant porcine pregnancy-associated glycoprotein-2. Journal of Biochemistry 144 725-732. (doi:10.1093/jb/mvn127)

Telugu BP, Walker A \& Green J 2009 Characterization of the bovine pregnancy-associated glycoprotein gene family - analysis of gene sequences, regulatory regions within the promoter and expression of selected genes. BMC Genomics 10 185. (doi:10.1186/1471-216410-185)

Telugu BP, Palmier MO, Van Doren SR \& Green JA 2010 An examination of the proteolytic activity for bovine pregnancy-associated glycoproteins 2 and 12. Biological Chemistry 391 259-270. (doi:10.1515/bc. 2010.016)

Touzard E, Reinaud P, Dubois O, Guyader-Joly C, Humblot P, Ponsart C \& Charpigny G 2013 Specific expression patterns and cell distribution of ancient and modern PAG in bovine placenta during pregnancy. Reproduction 146 347-362. (doi:10.1530/REP-13-0143)

Wallace JM, Aitken RP, Cheyne MA \& Humblot P 1997 Pregnancy-specific protein $\mathrm{B}$ and progesterone concentrations in relation to nutritional regimen, placental mass and pregnancy outcome in growing adolescent ewes carrying singleton fetuses. Journal of Reproduction and Fertility 109 53-58. (doi:10.1530/jrf.0.1090053)

Wathes DC \& Wooding FB 1980 An electron microscopic study of implantation in the cow. American Journal of Anatomy 159 285-306. (doi:10.1002/aja.1001590305)

Weems YS, Lammoglia MA, Vera-Avila HR, Randel RD, Sasser RG \& Weems CW 1998a Effects of luteinizing hormone (LH), PGE2, 8-EpiPGE1, 8-Epi-PGF2 $\alpha$, trichosanthin and pregnancy specific protein B (PSPB) on secretion of prostaglandin (PG) E (PGE) or F2 $\alpha$ (PGF2 $\alpha$ ) in vitro by corpora lutea (CL) from nonpregnant and pregnant cows. Prostaglandins \& Other Lipid Mediators 55 359-376. (doi:10.1016/ S0090-6980(98)00030-6)

Weems YS, Lammoglia MA, Vera-Avila HR, Randel RD, King C, Sasser RG \& Weems CW 1998b Effect of luteinizing hormone (LH), PGE2, 8-EpiPGE1, 8-EPI-PGE2, trichosanthin, and pregnancy specific protein B on secretion of progesterone in vitro by corpora lutea $(\mathrm{CL})$ from nonpregnant and pregnant cows. Prostaglandins \& Other Lipid Mediators 55 27-42. (doi:10.1016/S0090-6980(98)00003-3)

Weems YS, Kim L, Humphreys V, Tsuda V \& Weems CW 2003 Effect of luteinizing hormone $(\mathrm{LH})$, pregnancy specific protein $\mathrm{B}$ (PSPB), or arachidonic acid (AA) on ovine endometrium of the estrous cycle or placental secretion of prostaglandins E2 (PGE2) and F2 $\alpha$ (PGF2 $\alpha$ ) and progesterone in vitro. Prostaglandins \& Other Lipid Mediators 71 55-73. (doi:10.1016/S0090-6980(03)00004-2)

Whitworth KM, Spate LD, Li R, Rieke A, Sutovsky P, Green JA \& Prather RS 2010 Activation method does not alter abnormal placental gene expression and development in cloned pigs. Molecular Reproduction and Development 77 1016-1030. (doi:10.1002/mrd. 21235)

Willard ST, Petty SJ, Sasser RG, White DL \& Randel RD 1999 Pregnancy detection and the effects of age, body weight, and previous reproductive performance on pregnancy status and weaning rates of farmed fallow deer (Dama dama). Journal of Animal Science 77 32-38.

Wood AK, Short RE, Darling AE, Dusek GL, Sasser RG \& Ruder CA 1986 Serum assays for detecting pregnancy in mule and white-tailed deer. Journal of Wildlife Management 50 684-687. (doi:10.2307/3800981)

Wooding FB 1983 Frequency and localization of binucleate cells in the placentomes of ruminants. Placenta 4 527-540.

Wooding FB 1984 Role of binucleate cells in fetomaternal cell fusion at implantation in the sheep. American Journal of Anatomy 170 233-250. (doi:10.1002/aja.1001700208)

Wooding FB, Flint AP, Heap RB, Morgan G, Buttle HL \& Young IR 1986 Control of binucleate cell migration in the placenta of ruminants. Journal of Reproduction and Fertility 76 499-512. (doi:10.1530/jrf.0. 0760499)

Wooding FB, Roberts RM \& Green JA 2005 Light and electron microscope immunocytochemical studies of the distribution of pregnancy-associated glycoproteins (PAGs) throughout pregnancy in the cow: possible functional implications. Placenta 26 807-827. (doi:10.1016/j.placenta. 2004.10.014)

Wooding FB, Kimura J, Fukuta K \& Forhead AJ 2007 A light and electron microscopical study of the Tragulid (mouse deer) placenta. Placenta 28 1039-1048. (doi:10.1016/j.placenta.2007.04.010)

Xie SC, Low BG, Nagel RJ, Kramer KK, Anthony RV, Zoli AP, Beckers JF \& Roberts RM 1991 Identification of the major pregnancy-specific antigens of cattle and sheep as inactive members of the aspartic proteinase family. PNAS 88 10247-10251. (doi:10.1073/pnas.88.22.10247)

Xie S, Green J, Bixby JB, Szafranska B, DeMartini JC, Hecht S \& Roberts RM 1997 The diversity and evolutionary relationships of the pregnancyassociated glycoproteins, an aspartic proteinase subfamily consisting of many trophoblast-expressed genes. PNAS 94 12809-12816. (doi:10. 1073/pnas.94.24.12809)

Yoshimura M, Ihara Y, Ohnishi A, ljuhin N, Nishiura T, Kanakura Y, Matsuzawa Y \& Taniguchi N 1996 Bisecting $N$-acetylglucosamine on K562 cells suppresses natural killer cytotoxicity and promotes spleen colonization. Cancer Research 56 412-418.

Zhao P, Metcalf M \& Bunnett NW 2014 Biased signaling of proteaseactivated receptors. Frontiers in Endocrinology 5 67. (doi:10.3389/ fendo.2014.00067)

Zoli AP, Beckers JF, Wouters-Ballman P, Closset J, Falmagne P \& Ectors F 1991 Purification and characterization of a bovine pregnancy-associated glycoprotein. Biology of Reproduction 45 1-10. (doi:10.1095/biolreprod45.1.1)

Zoli AP, Guilbault LA, Delahaut P, Ortiz WB \& Beckers JF 1992 Radioimmunoassay of a bovine pregnancy-associated glycoprotein in serum: its application for pregnancy diagnosis. Biology of Reproduction 46 83-92. (doi:10.1095/biolreprod46.1.83)

Received 17 September 2014

First decision 20 October 2014

Revised manuscript received 27 November 2014

Accepted 5 December 2014 